\title{
FENOMENA MIGRASI DAN URBAN BIAS DI INDONESIA
}

\author{
Nasrullah Hidayat \\ Program Studi Administrasi Publik, Fakultas Ilmu Sosial dan Politik, UMA \\ Jalan Kolam No. 1 Medan Estate, Medan, 20223, Indonesia \\ e-mail: nasrullahhidayat@staff.uma.ac.id
}

\begin{abstract}
Abstrak
Penulisan ini bertujuan mengkaji feneomena migrasi di Indonesia. Maraknya urbanisasi dalam artian migrasi pun menyebabkan kerugian baik untuk desa maupun untuk kota, hanya dalam waktu 20 tahun penduduk kota bertambah hampir 50\%, sebaliknya setengah penduduk desa sekarang mengalami perubahan menjadi penduduk kota. Pada tahun 2005 jumlah penduduk kota sebesar 47,9\% sementara pada tahun 2025 jumlah penduduk kota diprediksikan akan meningkat menjadi 68\% Meningkatnya urbanisasi membuat kemiskinan terkonsentrasi di kota,akan tetapi hal ini terjadi karena adanya pandangan masyarakat desa bahwa kota merupakan harapan nyata dalam memutus rantai kemiskinan kemiskinan. Terjadinya migrasi diperkotaan atau ( urbanisasi) tidak akan menjadi masalah jika pemerintah dari kota-kota tujuan para migran mampu menciptakan lapangan kerja dan fasilitas publik yang mencukupi. Namun bila saja daya dukung kota sebagai suatu tempat publik sudah berada pada level yang kritis, maka pememrintah melalui berbagai macam kebijakannnya perlu turun tangan guna mengurangi dampak buruk dari urbanisasi tersebut. Urbanisasi berlebih perlu dikendalikan agar tidak berkembang makin liar dan semakin membebani kota-kota tujuan kaum migran.
\end{abstract}

Kata kunci: Fenomena, Migrasi, Urban Bias

\begin{abstract}
The Study purpose to discuss the migration phenomenon in Indonesia. The rise of urbanization in the sense of migration also causes losses both for villages and for cities, in just 20 years increased by almost $50 \%$, on the contrary half the village population is now becoming residents of the city. In 2005 the population of the city was 47.9\% while in 2025 the population of the city was predicted to increase to $68 \%$. Increased urbanization made poverty concentrated in the city, but this happened because of the view of the village community that the city represented the best hope for getting out of poverty. The occurrence of urban migration or (urbanization) will not be a problem if the government of the destination cities of migrants is able to create adequate employment and public facilities. But if the carrying capacity of the city as a public place is at a critical level, the government through various policies needs to intervene to reduce the adverse effects of urbanization. Excessive urbanization needs to be controlled so that it does not grow wilder and increasingly burden cities of migrants.
\end{abstract}

Key words: Phenomenon, Migration, Urban Bias

\section{PENDAHULUAN}

Pembangunan yang terjadi hingga saat ini di Negara Berkembang salahsatunya Indonesia masih menunjukkan ketimpangan pembangunan antara kota dengan desa, atau dapat dikatakan urban bias. Adanya ketimpangan pembangunan antara desa dan kota tersebut menghasilkan ketimpangan kesejahteraan, dimana kesejahteraan kota lebih tinggi dibandingkan di desa.

Hal ini menimbulkan terjadinya fenomena urbanisasi yang dapat diartikan terjadinya proses pengkotaan yaitu migrasi 
dari desa ke kota. Data BPS mencatat terjadi pemekaran jumlah kota yang signifikan, selama 38 tahun jumlah kota otonom telah pertambahan mencapai dua kali lipat. Fenomena urbanisasi atau berkurangnya desa akibat proses pengkotaan terjadi dengan cepat selama beberapa tahun terakhir dan hal ini merupakan wujud dari pembangunan yang urban bias. Dari total 75.410 jumlah desa di Indonesia, sebanyak 24.716 desa telah mengalami proses pengkotaan dan degradasi lahan pertanian.

Lahan pertanian sebagai ciri khas fisik dari desa semakin berkurang sebesar $100.000 \mathrm{Ha} /$ tahun. Tereduksinya lahan pertanian tersebut dikarenakan besarnya tekanan dari industrialisasi yang muncul salah satunya akibat dari adanya penanaman modal asing ataupun dalam negeri. Jika hal ini tetap terjadi dan tidak ada kebijakan pembangunan yang menyentuh masyarakat dan melindungi keberadaan desa maka potensi sumber daya alam, pangan dan energi akan terancam. Penurunan cadangan air yang ditandai dari meningkatnya tingkat kerusakan DAS sebesar 5,4 juta Ha hanya dalam waktu 15 tahun dapat dijadikan sebagai peringatan awal sebelum terjadi krisis air akibat dari pembangunan yang tidak terarah.

Maraknya urbanisasi dalam artian migrasi pun menyebabkan kerugian baik untuk desa maupun untuk kota, hanya dalam waktu 20 tahun penduduk kota bertambah hampir 50\%, sebaliknya setengah penduduk desa sekarang ini bertransformasi menjadi penduduk kota. Menurut data BPS pada tahun 2010 jumlah penduduk kota sebesar 47,9\% sementara pada tahun 2025 jumlah penduduk kota diprediksikan akan meningkat menjadi $68 \%$ (BPS, 2010-2035).

Secara demografi dan kependudukan, kecenderungan peningkatan penduduk ke kota juga mengalami tren yang meningkat. Bappenas menyimpulkan, pada tahun 2014 penduduk Indonesia sudah lebih banyak di kota dibandingkan di desa. Meningkatnya urbanisasi membuat kemiskinan terkonsentrasi di kota, akan tetapi hal ini terjadi karena adanya pandangan masyarakat desa bahwa kota mewakili harapan mereka dan salahsatu upaya mengubah stratfikasi sosial agar lepas dari jeratan kemiskinan.

Sedangkan untuk desa, dengan berpindahnya penduduk ke kota akan menyebabkan berkurangnya tenaga kerja di desa sehingga potensi sumber daya alam desa menjadi tak terkelola. Berkurangnya penduduk dan jumlah desa ternyata menimbulkan banyak dampak turunan berupa hilangnya keseimbangan wilayah sehingga kota (sebagai pusat pertumbuhan) kehilangan daya dukungnya.

Seiring dengan berjalannya waktu, kondisi tersebut akan mengakibatkan degradasi pada kota sehingga diperlukan upaya untuk mempertahankan desa. Tantangan-tantangan tersebut mengarah kepada pembangunan yang seyogyanya memperhatikan kewilayahan karena selama ini pembangunan yang urban bias membawa dampak buruk yaitu ketimpangan rural urban linkage yang ditunjukkan oleh fenomena back wash effect.

Oleh karena itu perhatian kepada pembangunan desapun harus mengutamakan keseimbangan dari rural urban linkage. Dalam hal ini, desa tidak dipandang sebagai sub-ordinat dari dari kota, namun hubungan desa dengan kota sudah seharusnya dipandang dalam konteks keseimbangan wilayah. Untuk itu perlu diwujudkan usaha menjaga keberlanjutan desa-desa yang ada dan mulai menciptakan desa yang memiliki daya tarik dan daya saing sehingga fenomena urbanisasi dapat dicegah. Permasalahan tersebut diperkuat dengan keputusan penduduk desa untuk bermigrasi termotivasi karena kurangnya peluang ekonomi di desa. Dengan tingkat pendapatan rata-rata di kota berpenghasilan tinggi lebih dari daripada di desa berpenghasilan rendah. Tidak mengherankan bahwa banyak orang di negara desa merasa terdorong untuk mencoba peruntungan di kota. 
Tren ini diperkuat oleh pergeseran demografis. Karena kota berpenghasilan tinggi menghadapi penuaan populasi. Gangguan teknologi juga memberi tekanan pada pasar tenaga kerja. Selain itu, perubahan iklim, sebagaimana ditunjukkan oleh laporan Bank Dunia baru-baru ini, akan mempercepat tren, dengan mengusir sekitar 140 juta orang dari rumah mereka dalam beberapa dekade mendatang. (https://www.weforum.org/agenda/2019 /03/migration-myths-vs-economic-facts/).

Secara makro di Negara berkembang migran yang menetap di suatu negara memberikan kontribusi besar. Meskipun diperkirakan dunia 266 juta migran hanya terdiri dari sekitar 3,4\% dari populasi global, mereka berkontribusi lebih dari 9\% dari PDB. Untuk mencapai ini, para migran harus mengatasi hambatan yang tinggi untuk keberhasilan ekonomi. Misalnya, pekerja tidak terampil, terutama mereka yang berasal dari negara miskin, sering membayar biaya yang sangat tinggi yang dapat melebihi pendapatan setahun penuh untuk pekerja migran di beberapa negara tujuan - kepada agen tenaga kerja yang tidak bermoral untuk mencari pekerjaan di luar negara mereka sendiri. Itulah sebabnya Tujuan Pembangunan Berkelanjutan (SDGs) mencakup target untuk mengurangi biaya rekrutmen.

Migrasi juga memberikan manfaat ekonomi besar ke negara asal. Sementara migran menghabiskan sebagian besar upah mereka di negara tuan rumah meningkatkan permintaan di sana - mereka juga cenderung mengirim uang untuk mendukung keluarga di rumah. Pengiriman uang semacam itu diketahui melebihi bantuan pembangunan resmi. Tahun lalu, pengiriman uang ke negaranegara berpenghasilan rendah dan menengah meningkat sebesar $11 \%$, mencapai \$ 528 miliar, melebihi arus masuk investasi langsung asing negara-negara tersebut (World Economic Forum, 2018).

Tidak semua aspek migrasi bermanfaat bagi negara berkembang. Migrasi dapat menimbulkan biaya tinggi bagi negara-negara berkembang dengan meninggalkan negara tanpa modal manusia yang diperlukan untuk mencapai pertumbuhan ekonomi jangka panjang. Pelarian sumber daya manusia ini dapat menimbulkan beban ekonomi yang signifikan bagi negara-negara berkembang karena para migran membawa nilai pelatihan mereka, yang seringkali disubsidi oleh pemerintah dengan sumber daya terbatas.

Sementara migrasi berdampak pada pembangunan, kondisi ekonomi merupakan pendorong penting migrasi. Orang bermigrasi karena berbagai alasan termasuk mencari peluang ekonomi yang lebih baik, pendidikan, reuni keluarga dan melarikan diri dari kekerasan. Orang sering bermigrasi untuk kombinasi dari ini dan alasan lainnya. Namun, kesenjangan pendapatan yang diharapkan antara negara maju dan berkembang adalah insentif yang kuat bagi orang untuk bermigrasi (Czaika dan de Haas 2011a). Karena itu, migrasi memengaruhi pembangunan, tetapi pembangunan juga memengaruhi migrasi.

Seperti dijelaskan diatas, ini bukan hubungan yang sederhana. Pembangunan tidak selalu mengarah pada migrasi yang lebih sedikit. Sulit ditemukan faktor mana yang dominan, yang mempengaruhi migrasi. Namun, dari berbagai penelitian sudah dilaksanakan bahwa terlihat banyak faktor utama yang mempengaruhi migrasi adalah faktor ekonomi. Menurut (Mantra, 2007) menyatakan bahwa kondisi ekonomi didaerah asal yang tidak mendukung biaya sehari-hari seseorang akan mendorongnya mencari pekerjaan didaerah lain. Hal itu dilakukan dengan harapan untuk memperoleh pendapatan yang lebih tinggi dan memperbaiki ekonomi keluarganya.

Menurut (Lee, 1966) banyak faktor yang mempengaruhi terjadinya migrasi. Besar kecilnya volume migrasi dipengaruhi oleh adanya push factor dan full factor di daerah tujuan, jarak antara kedua daerah, serta faktor individual dari migran. 


\section{PEMBAHASAN}

\section{Urban Bias di Negara Berkembang}

Di negera berkembang fenomena urban bias hanya menguntungkan kelompok-kelompok tertentu. Seperti halnya urban bias mengacu pada argumen ekonomi politik yang menurut teori pembangunan, ekonomi terhambat oleh kelompok-kelompok yang lokasi pusatnya di daerah perkotaan, dapat menekan pemerintah untuk melindungi kepentingan mereka.

Teori perkembangan kota yang berlebihan dan 'bias perkotaan' memiliki sejarah panjang, tetapi tidak berlanjut, yang berasal dari tahun 1920-an ketika pembuat kebijakan di bekas Uni Soviet mempertimbangkan keseimbangan sektoral perkotaan-pedesaan dalam pembangunan ekonomi terencana. Gagasan tentang bias perkotaan terus memiliki relevansi dalam kebijakan ekonomi makro dan perdagangan (terutama di banyak negara berkembang) sejak 1960-an. Meskipun teori keseimbangan ekonomi perkotaanpedesaan dan bias perkotaan memiliki signifikansi mendasar untuk pengembangan ekonomi perkotaan, banyak relevansinya yang tidak diakui atau disalahpahami. Namun, adalah tepat untuk meninjau keadaan teori bias perkotaan dari perspektif tahun 1990-an.

Hasil beberapa penelitian modern menjelaskan masalah-masalah luar biasa dari kontroversi masa lalu; dalam konteks negara-negara berkembang, Bank Dunia dan pembuat kebijakan terkemuka lainnya telah mengadvokasi hubungan yang lebih dekat antara makroekonomi dan pengembangan kebijakan perkotaan; dan kebijakan ekonomi untuk penyesuaian struktural secara tidak langsung menghilangkan beberapa struktur yang mendukung ekonomi politik dari bias perkotaan. Dengan demikian, bahkan jika bias perkotaan dan pengembangan kota yang berlebihan memiliki beberapa elemen misterius dalam sejarah mereka dan hubungannya dengan ekonomi pembangunan, subjek memiliki kepentingan dalam konteks pasca-1990.
Hubungan antara bias perkotaan, ekonomi politik pembangunan dan proses perkotaan dan kebijakan untuk negara-negara berkembang sangat erat (Pugh, 1996).

\section{Fenomena Urban Bias}

Sebagai catatan sejarah (Sechele, 2016) menjelaskan pada periode antara akhir Perang Dunia Kedua dan 1970, pembangunan sebagian besar dirasakan dalam hal ekonomi. Akar penyebab kemiskinan di negara-negara yang kurang berkembang dikaitkan dengan faktor-faktor seperti kurangnya nilai kewirausahaan, penggunaan teknologi tradisional atau kurang produktif, dan kurangnya pertumbuhan ekonomi. Negara-negara Barat dikatakan telah lama mengatasi rintangan-rintangan ini dan karena itu merupakan model untuk pembangunan (Rostow, 1960). Agar negara-negara yang kurang berkembang dapat mengejar ketinggalannya, pertumbuhan ekonomi dipandang sebagai prasyarat. Tujuannya adalah untuk mencapai melalui industrialisasi dan bahkan dengan mengorbankan pertanian dan pembangunan pedesaan.

Diperkirakan bahwa manfaat pertumbuhan ekonomi akan mengalir ke massa orang miskin (Todaro, 1989). Studi yang dilakukan pada 1970-an telah mengungkapkan bahwa manfaat pertumbuhan ekonomi belum mampu mencapai mayoritas seperti yang dibayangkan. Pertumbuhan telah didistribusikan secara tidak merata di antara negara-negara, wilayah di dalam negara dan kelompok sosial-ekonomi (Chenery, 1974). 5\% dari penerima pendapatan terkaya di negara-negara kurang berkembang menerima bagian pendapatan yang enam kali 20\% termiskin (Fields, 1980).

Kegigihan kemiskinan dan ketimpangan di tengah pertumbuhan menuntut perubahan konsepsi pembangunan. Strategi pembangunan dipandu oleh tujuan mengurangi kesenjangan sosial untuk memaksimalkan keadilan distributif. Beberapa teori harus 
dirumuskan untuk menjelaskan kegigihan kemiskinan dan bagaimana kemiskinan itu bisa diberantas.

Seperti yang ditemukan oleh (Todaro dan Stilkind, 1981) bahwa kegiatan industrialisasi di NSB sangat urban bias sehingga dapat menyebakan kemiskinan, dampaknya sektor tradisional di perdesaan tidak terlaksana dengan baik. Oleh karena itu probelma disparitas ekonomi antara desa dan kota semakin lama semakin meningkat. Kedepannya para ahli Demografi memprediksikan bahwa proses urbanisasi di Negara Berkembang terutama di Indonesia lebih banyak lagi disebabkan oleh pergerakan migrasi desa-kota.

Proyeksi tersebut didasarkan atas semakin menurunnya pertumbuhan alamiah penduduk di daerah perkotaan, serta relatif melambatnya reklasifikasi status dari perdesaan menjadi daerah perkotaan, serta relatif kuatnya kebijakan ekonomi dan pembangunan yang bersifat urban bias tersebut sehingga memperbesar daya tarik daerah perkotaan bagi penduduk yang tinggal di daerah perdesaan. Sehingga di masa mendatang, isu urbanisasi dan migrasi penduduk menjadi sulit untuk dipisahkan dan akan menjadi isu yang penting dalam kebijakan kependudukan di Indonesia.

Ditambah lagi isu kelahiran (fertilitas) dan kematian masih mendominasi kebijakan kependudukan di Indonesia. Pada masa mendatang jika diasumsikan tingkat kelahiran dan kematian sudah menjadi rendah, ukuran keluarga menjadi kecil, dan sebaliknya kesejahteraan keluarga dan masyarakat meningkat, maka keinginan untuk melakukan migrasi bagi sebagaian besar penduduk akan semakin meningkat terutama yang menuju daerah perkotaan.

Misalnya saja pada tahun 1980, kaum migrasi di Indonesia berjumlah 3,7 juta jiwa, maka angka tersebut meningkat menjadi 5,2 juta jiwa pada tahun 1990 dan sedikit menurun menjadi 4, 3 juta jiwa pada periode 1990-1995. Secara kumulatif diketahui bahwa sampai tahun 1980, jumlah penduduk Indonesia yang pernah melakukan migrasi adalah 11,4 juta jiwa sedangkan pada tahun 1990 angka tersebut meningkat menjadi17,8 juta jiwa.

Lebih lanjut lagi, data survei penduduk antarsensus (SUPAS) 1995 memperlihatkan bahwa tingkat urbanisasi di Indonesia pada tahun 1995 adalah 35,91 persen yang berarti bahwa 35,91 persen penduduk Indonesia tinggal didaerah perkotaan. Tingkat ini telah meningkat dari sekitar 22,4 persen pada 1980 yang lalu. Dan sebaliknya proporsi penduduk yang tinggal didaerah perdesaan mnurun 77,6 persen pada tahun 1980 menjadi 64,09 persen pada tahun 1995.

Laju pertumbuhan proses urbanisasi tersebut tidak terlepas dari kebijakan pembangunan perkotaan, seperti pembangunan ekonomi yang dikembangkan oleh pemerintah. Kita ketahui peningkatan jumlah penduduk didaerah perdesaan akan berkorelasi positif dengan meningkatnya arus urbanisasi jika pola pembangunan masih bias ke arah kota (urban bias). Ada kecenderungan bahwa akativitas perekonomian akan terpusat pada suatu area yang memiliki tingkat konsentrasi penduduk yang cukup tinggi.

Korelasi positif antara konsentrasi penduduk dengan aktivitas kegiatan ekonomi ini akan menyebabkan makin membesarnya area konsentrasi penduduk, sehingga menimbulkan apa yang dikenal dengan nama daerah perkotaan.

Data dan fakta tersebut membuktikan bahwa adanya keterkaitan timbal balik antara aktivitas ekonomi dengan konsentrasi penduduk. Para aktor ekonomi cenderung melakukan investasi di daerah yang memiliki sarana dan prasarana yang lengkapdisebabkan dapat menghemat bebagai biaya, antara lain biaya distribusi barang dan jasa. Sebaliknya, penduduk akan cenderung datang kepada pusat kegiatan ekonomi karena ditempat itulah mereka akan lebih mudah memperoleh kesempatan untuk mendapatkan pekerjaan.

Dengan demikian, urbanisasi merupakan suatu proses yang yang wajar dalam upaya meningkatkan kesejahteraan penduduk atau masyarakat. Urbanisasi 
penting untuk diarahkan melalui kebijakan sebagai berikut:

1. Pemerintah berkeinginan untuk sesegera mungkin meningkatkan proporsi penduduk yang tinggal didaerah perkotaan. Hal ini berhubungan dengan adanya kenyataan bahwasanya meningkatnya penduduk di daerah perkotaan akan berkaitan erat dengan meningkatnya pertumbuhan ekonomi suatu negara. Data empiris memperlihatkan suatu negara atau daerah dengan tingkat perekonomian yang tinggi, cenderung akan memiliki tingkat urbanisasi yang tinggi pula, dan sebaliknya. Negara-negara industri pada umumnya memiliki tingkat urbanisasi diatas 75 persen. Bandingkan dengan negara berkembang sekarang ini. Tingkat urbanisasinya masih sekitar 35 persen sampai dengan 40 persen saja.

2. Terjadinya tingkat urbanisasi yang berlebihan, atau tidak terkendali dapat menimbulkan berbagai perrmasalahan pada penduduk itu sendiri. Ukuran terkendali atau tidaknya proses urbanisasi biasanya dikenal dengan ukuran primacy rate, yang kurang lebih diartikan sebagai kekuatan daya tarik kota terbesar pada suatu negara atau wilayah terhadap kota-kota disekitarnya. Makin besar primacy rate menunjukkan kedaaan yang kurang baik dalam proses urbanisasi.

Namun disisi lain, bagi kota-kota tujuan migran, arus urbanisasi yang berlebih (over urbanization) dapat pula menjadi masalah serius, bukan sekedar terjadinya penumpukan kaum migran di sektor informal diperkotaan. Lebih dari itu, kehadiran kaum migran yang berlebihan tersebut dapat menyebabkan lahirnya berbagai persoalan sosial di perkotaan. Secara umum motivasi penduduk desa melakukan urbanisasi ke kota adalah karena tekanan kemiskinan dan keinginan untuk memperoleh sumber penghidupan yang lebih baik.

Setidaknya ada tiga alasann utama mengapa penduduk diperdesaan cenderung memiliki" hasrat" untuk bermigrasi di perkotaan yaitu pertama, sejak krisis melanda negeri ini semakin hari kesempatan kerja didaerah perdesaan semakin langka, sementara usaha yang sebelumnya ditekuni (pengrajin, pedagang dan lain sebagainya) mengalami kebangkrutan akibat krisis. Kedua adanya selisih upah yang cukup mencolok antara desa dan kota, hal tersebut salahsatunya tercermin pada perbedaan upah minimum regional antara daerah pinggiran dengan dan daerah pusat kegiatan ekonomi.

Upah didesa dinilai hanya cukup untuk sekedar bertahan hidup (subsisten). Ketiga, dilura faktor ekonomi alasan yang cukup dominan mendorong penduduk desa untuk mangadu nasib di kota adalah karena masalah keluarga ataua sesuatu hal yang sifatnya personal. Untuk sebagain besar penduduk miskin di perdesaan, selain menawarkan kesempatan kerja yang lebih terbuka, kota juga dinilai memiliki "daya tarik" tertentu. Disisi lain, banyak studi yang membuktikan bahwasanya kehadiran kaum kaum migran di daerah perkotaan sebenarnya merupakan salahsatu respon dari adanya ketidakmerataan pembangunan antar daerah dan semakin kronisnya masalah kemiskinan di daerah perdesaan.

Terjadinya migrasi diperkotaan atau (urbanisasi) tidak akan menjadi masalah jika pemerintah dari kota-kota tujuan para migran mampu menciptakan lapangan kerja dan fasilitas publik yang mencukupi. Namun bila saja daya dukung kota sebagai suatu tempat publik sudah berada pada level yang kritis, maka pememrintah melalui berbagai macam kebijakannnya perlu turun tangan guna mengurangi dampak buruk dari urbanisasi tersebut. Urbanisasi berlebih perlu dikendalikan agar tidak berkembang makin liar dan semakin membebani kota-kota tujuan kaum migran. Arus urbanisasi berlebih tersebut tidak hanya dapat tereleminasi hanya dengan penerapan kebijakan pintu tertutup dan membatasi arus migrasi secara sepihak. Kebijakan pintu tertutup hanya dapat berjalan efektif jika diimbangi dengan adanya upaya menciptakan kesempatan 
kerja dan mengurangi kesenjangan desakota.

Satu Fenomena yang menarik untuk dicermati adalah adanya proses modernisasi pertanian. Tanpa disadari adanya modernisasi di bidang pertanian malah akan mengurangi kesempatan kerja di sektor tesebut. Seiring dengan proses modernisasi, pola investasi di sektor pertanian pun turut berkembang, sekarang pola investasinya lebih bersifat menghemat tenaga kerja (labour saving), karena tenaga manusia pengolah lahan - lahan pertanian telah tergantikan oleh mesin-mesin yang serba otomatis. Dengan demikian, tidak ada pilihan lain yang dapat dilakukan penduduk desa, kecuali melakukan urbanisasi ke kota-kota besar.

Untuk menangani permasalahan urbanisasi berlebih di daerah perkotaan, rasanya sangat tidak adil jika para migran yang pada awalnya terkonsentrasi di sektor informal perkotaan hanya diperlakukan sebgai pengganggu keindahan dan ketertiban kota. Akibatnya, mereka layak untuk di razia, digaruk, kemudian dipulangkan ke daerahnya masing-masing. Migrasi liar yang menempati zona - zona publik perlu diatur dan ditertibkan agar tidak melanggar hak warga kota lainnya.

Dibalik itu semua, satu solusi yang dibutuhkan untuk dapat mememcahkan masalah permaslahan urbanisasi yang kian kompleks adalah kerangka kebijakan makro di tingkat regional untuk mempercepat pembangunan kota-kota sekunder agar mampu menyediakan lapangan kerja bagi penduduk desa yang berkeinginan mengadu nasib kibat keterbatasan kesempatan kerja didaerah salnya. Disisi lain, pada umumnya, para lembaga pemberi bekal keterampilan, sehingga perlu ada semacam lembagalembaga pemberi bekal keterampilan bagi penduduk usia kerja. Agar tanpa harus bermigrasi, maka dapat mengembangkan usaha didaerah asalnya sesuai dengan keterampilan dan kondisi ekonomi di daerahnya.

\section{Kebijakan Migrasi}

Sementara komunitas internasional telah lama mengakui hubungan penting antara migrasi dan pembangunan internasional, integrasi para migran dan migrasi ke dalam Agenda 2030 untuk Pembangunan Berkelanjutan merupakan langkah maju yang penting.

Secara khusus, target 10.7 dari Tujuan Pembangunan Berkelanjutan menyerukan kepada negara-negara untuk memfasilitasi migrasi dan mobilitas orang yang tertib, aman, teratur dan bertanggung jawab, termasuk melalui implementasi kebijakan migrasi yang terencana dan terkelola dengan baik.

Target terkait migrasi lainnya dalam Agenda 2030 termasuk mempertahankan pekerja kesehatan di negara berkembang; menyediakan beasiswa untuk belajar di luar negeri; mengakhiri perdagangan manusia; menghormati hak-hak pekerja migran, khususnya migran perempuan; mengurangi biaya transfer pengiriman uang dan memberikan identitas hukum untuk semua.

Pemisahan data dengan berbagai karakteristik, termasuk status migrasi, adalah target lintas sektoral yang dapat membantu mengidentifikasi kerentanan khusus migran dan memastikan pembangunan yang inklusif. Serangkaian kebijakan ini mengakibatkan perkembangan kota sangat pesat sehingga meninggalkan wilayah sekitarnya. Trickle down effect yang diharapkan muncul dari konsep ini tidak berjalan dan malah mengakibatkan tingkat kesenjangan antar wilayah semakin besar. Fenomena kota primasi, pada kawasan misalnya di Indonesia kawasan Jabotabek, menunjukkan ketimpangan dan kesenjangan yang besar antara kota besar dengan kota sekitarnya.

\section{Development Approach}

Dalam pembangunan dikenal adanya dua pendekatan yang dilakukan dalam usaha meningkatkan pertumbuhan pada sektor ekonomi. Pendekatan pertama mengemukakan bahwa investasi pada 
sektor pertanian dapat menyediakan modal bagi pengembangan industri dan perkotaan, sementara itu pendekatan kedua mengemukakan bahwa pertumbuhan industri dan perkotaan menjadi syarat bagi sektor pertanian yang lebih modern dan produktif. Teori dan pelaksanaan pembangunan baik yang dilakukan di Indonesia maupun negara lain sebagian besar masih mendikotomikan antara kota dan desa baik dalam hal lokasi, penduduk maupun aktivitas, yang tercermin dengan adanya dualisme pembangunan antara perkotaan dan perdesaan yang menyebabkan terjadinya distorsi hubungan antara perkotaan dan perdesaan.

Pembangunan yang lebih banyak difokuskan di perkotaan (memfokuskan pada pembangunan industri) dibandingkan di perdesaan (melalui pembaharuan sektor pertanian) menyebabkan terjadinya urban bias yang mencerminkan alokasi sumberdaya yang lebih berpihak pada kota. Pada sisi lain, dalam perencanaan kota biasanya hanya terkonsentrasi di perkotaan dan sedikit menyinggung sektor pertanian, sedangkan perencanaan pembangunan perdesaan cenderung mengabaikan perkotaan dan mendefinisikan wilayah perdesaan hanya desa dengan areal pertaniannya saja.

Hal-hal tersebut menyebabkan pembangunan pada kota menimbulkan permasalahan seperti urbanisasi dan sektor informal yang tidak terkontrol, di sisi lain pada wilayah perdesaan terjadi tekanan terhadap penduduk dan sumber daya alam, timbulnya kemiskinan di perdesaan, degradasi lingkungan serta merenggangnya hubungan sosial yang ada.

Kebijakan dan situasi yang kemudian menimbulkan push factor dan pull factor misalnya dalam arus migrasi masuk penduduk ke Kota Jakarta pada saat lebaran, walau data menunjukkan bahwa arus ini terjadi sepanjang tahun dimana Lebaran hanya salah satu momen saja dari arus migrasi masuk ini. Push factor seperti kemiskinan didesa, ketiadaan lapangan kerja, semakin sempitnya lahan pertanian, dan lain sebagainya diyakini sebagai komponen utama yang merangsang penduduk untuk meninggalkan daerahnya dan menuju kawasan perkotaan yang lebih maju (salah satunya kota Jakarta).

Pull factor yang menjadi penarik arus migrasi masuk tercipta dari; figurfigur kesuksesan yang muncul pada saat mudik, monumen-monumen materialistis kehidupan kota Jakarta yang terlihat di Sinetron-sinetron, pembangunan kota Jakarta yang gemerlap dengan infrastruktur kelas atasnya dan lain sebagainya.

\section{a. Policy of Migration in Developed Countries}

Beberapa negara maju juga memiliki permasalahan sama dalam hal semakin besarnya gelombang migrasi yang masuk ke negaranya. Oleh karena itu Brock mengusulkan kebijakan migrasi. Kebijakan tersebut kurang lebih mengatur kuota migran, melakukan seleksi migran, menentukan batas waktu kerja migran dan melakukan perjanjian yang menguntungkan banyak pihak (Brock, 2010). Permasalahan lainnya adalah para imigran kemungkinan akan mengancam budaya lokal atau solidaritas penduduk lokal. Namun menurut Brock hal ini bukanlah suatu ancaman, karena setiap negara saat ini telah berlomba untuk keluar dari sekat tersebut.

Dalam tulisannya (Cuccioletta, 2001), dengan tegas mengungkapkan bahwa cultural clashes akan muncul ketika manusia melakukan perpindahan walaupun hanya di dalam negaranya sendiri. Penyebab dari konflik tersebut biasanya adalah kebencian terhadap perbedaan budaya, tidak mampu menerima budaya yang baru dan adanya stereotype negatif akan kelompok masyarakat budaya lain.

Resolusi terhadap konflik migrasi sudah banyak dilakukan. Misalnya seperti yang diusulkan oleh Brock dengan melakukan perjanjian sistemik dengan migran. Selain itu pemerintah lokal juga mengeluarkan kebijakan multikulturalisme, seperti yang dilakukan pemerintah Kanada pada tahun 1972 (Cuccioletta, 2001). 
Penerimaan dan praktek terhadap kebijakan multikulturalisme tersebut akan menciptakan penduduk yang kosmopolitan. Penduduk cosmopolitan menyadari bahwa setiap orang dalam sebuah negara memiliki identitas multi, yang tidak hanya berhubungan dengan satu kebudayaan warisan, tetapi juga kebudayaan host country, benua, lingkungan tempat tinggal dan sebagainya (Cucioletta, 2001).

$$
\text { Dapat dikatakan bahwa, }
$$
multikulturalisme sebenarnya terjadi karena migrasi di seluruh dunia. Lebih jauh globalisasi memberikan dampak yang signifikan terhadap multikulturalisme. Globalisasi memunculkan ide baru terhadap identitas atau budaya tunggal karena adanya rasa termarjinalkan. Kemudian pemahaman akan Global Village juga menimbulkan dampak bahwa dunia sebagai satu tempat tinggal dan mulai membiaskan identitas nasional.

\section{b. Cosmopolitanism}

2006), $\begin{array}{rrr}\text { Menurut (Walker dan } & \text { Serrano } \\ \text { memperjelas } & & \text { konsep }\end{array}$ multikulturalisme yang bersinonim dengan pluralisme, dan kosmopolitanisme adalah bentuk yang lebih tinggi. Kosmopolitanisme ini tercipta ketika kedua kelompok, migran dan penduduk lokal, mempraktekkan toleransi atas perbedaan (Hollinger dalam Walker dan Serrano, 2006). Untuk menciptakan keadaan itu, kosmopolitanisme sebaiknya disertakan dalam pendidikan. Edukasi kosmopolitan ini menurut Banks (dalam Walker dan Serrano, 2006) akan menciptakan pelajar yang memiliki multi identitas nasional dan memiliki profesionalitas dan komitmen personal di seluruh dunia.

Walker dan Serrano menyebutkan contoh kelompok minor yang kosmopolitan yaitu Otavalo. Otavalo merupakan minoritas dan didiskriminasi perdagangannya oleh Ekuador. Namun Otavalo mendapatkan bantuan dari Amerika dan Eropa. Akhirnya mereka mampu melakukan perjalanan ke luar negeri dan mempelajari budaya dan bahasa lain di seluruh dunia.

Dapat disimpulkan bahwa migran dan penduduk lokal berhubungan erat dengan kosmopolitanisme. Migrasi di seluruh dunia menciptakan multikulturalisme. Penduduk lokal dan migran yang mampu menggalakkan toleransi terhadap perbedaan di antara keduanya akan memunculkan penduduk yang kosmopolitan. Penulis menilai bahwa kosmopolitanisme sama seperti asimilasi. Dimana banyak budaya berkumpul dalam satu tempat dan perbedaan budaya tersebut menjadi bias, yang terpenting adalah toleransi dan solidaritas.

\section{KESIMPULAN}

Meningkatnya urbanisasi membuat kemiskinan terkonsentrasi di kota, akan tetapi hal ini terjadi karena adanya pandangan masyarakat desa bahwa kota mewakili harapan terbaik untuk keluar dari kemiskinan. Terjadinya migrasi diperkotaan atau (urbanisasi) tidak akan menjadi masalah jika pemerintah dari kotakota tujuan para migran mampu menciptakan lapangan kerja dan fasilitas publik yang mencukupi.

Namun bila saja daya dukung kota sebagai suatu tempat publik sudah berada pada level yang kritis, maka pemerintah melalui berbagai macam kebijakannnya perlu turun tangan guna mengurangi dampak buruk dari urbanisasi tersebut. Urbanisasi berlebih perlu dikendalikan agar tidak berkembang makin liar dan semakin membebani kota-kota tujuan kaum migran.

\section{UCAPAN TERIMA KASIH}

Terimakasih kepada instansi terkait yang telah memberikan data dan informasi khususnya Badan Pusat Statistik.

\section{DAFTAR PUSTAKA}

Badan Pusat Statistik Indonesia. (2013). Proyeksi Penduduk Indonesia Indonesia Population Projection 2010-2035. Jakarta: BPS 
Badan Perencanaan Pembangunan Nasional (Bappenas). (2014). Rencana Pembangunan Jangka Menengah Nasional (RPJMN) 2015-2019. Jakarta: Bappenas

Brock, G. (2010). Immigration and Global Justice: What kinds of policies should a Cosmopolitan support. Journal of Etica \& Politica / Ethics \& Politics, XII, pp. 362-376

Cuccioletta, D. (2001). Multiculturalism or Transculturalism: Towards a Cosmopolitan Citizenship. London Journal of Canadian Studies, Vol. (17). No.1, pp. 1-11.

http:/ / gabrielafisip10.web.unair.ac.id/artik el_detail-82328-Kosmopolitanisme diakses tanggal 30 Nopember 2019 https://www.republika.co.id/berita/nasio nal/umum/12/03/01/humaira/ibuan ak/14/04/08/pendidikan/duniakamp us/17/10/06/oxe7zn374-sejumlahpakar-bicara-keamanan-pangan-di-ipb
Lee, E. (1966). "Atheory of migration". Demography. Vol.3, p.47-57

Mantra, B.I. (2007). Demografi Umum. Yogyakarta: BPFE.

Sechele, L. (2016). Urban Bias, Economic Resource Allocation and National Development Planning in Botswana. International Journal of Social Science Research, 4 (1), 1-18

Supas. (2005). Profil Penduduk Indonesia Hasil Supas 2005. Jakarta: BPS

Todaro dan Stilkind. (1981). City Bias and Rural Neglect. The Dilemma Urbanof Urban Development. New York: The Population Council

Pugh, C. (1996). Urban Bias', the Political Economy of Development and Urban Policies for Developing Countries. Journal of Urban Studies, Sage Journals Publication, 1 (1), 1-9

Walker, Jeffrey P. and Anna M. Serrano. (2006). Formulating a Cosmopolitan 